\title{
Correction to: Anger and Absurdity
}

\section{Daniel Coren ${ }^{1}$}

Published online: 12 November 2021

(C) Springer Nature B.V. 2021

\section{Correction to: Ethical Theory and Moral Practice} https://doi.org/10.1007/s10677-021-10217-0

The original version of the article unfortunately contained an error.

Current reference:

- Tanaka K (2014) Anger and moral judgment. Australas J Philos 92:269-286

Should be:

- Pettigrove, G. \& Tanaka K. (2014) Anger and moral judgment. Australas J Philos 92:269-286

Publisher's Note Springer Nature remains neutral with regard to jurisdictional claims in published maps and institutional affiliations.

The online version of the original article can be found at https://doi.org/10.1007/s10677-021-10217-0

\section{Daniel Coren}

Daniel.coren@colorado.edu; corenda@mcmaster.ca

1 Department of Philosophy, McMaster University, Hamilton, Canada 